\title{
The Style of Nordic Noir : Bordertown as a Stylistic Adaptation of the Prototype
}

\section{Seppälä, Jaakko}

Palgrave Macmillan

2020

Seppälä , J 2020 , The Style of Nordic Noir : Bordertown as a Stylistic Adaptation of the Prototype . in J Seppälä , A Nestingen \& L Badley (eds), Nordic Noir, Adaptation, Appropriation . Palgrave Studies in Adaptation and Visual Culture, Palgrave Macmillan, pp. 255-273 . https://doi.org/10.1007/978-3-030-38658-0_14

http://hdl.handle.net/10138/338142

https://doi.org/10.1007/978-3-030-38658-0_14

acceptedVersion

Downloaded from Helda, University of Helsinki institutional repository.

This is an electronic reprint of the original article.

This reprint may differ from the original in pagination and typographic detail.

Please cite the original version. 


\section{The Style of Nordic Noir: Bordertown as a Stylistic Adaptation of the Prototype}

Nordic noir is a buzzword that is unavoidable in virtually all discourses surrounding contemporary Nordic crime films and television series of certain style. Nordic noir is an oxymoron. The word Nordic is closely connected to the five welfare states and the good life, according to statistical reports. The 2019 World Happiness Report ranked the Nordic countries among the ten happiest countries in the world, Finland being number one. Contrary to such measures, the French word noir (black) stands for dark crime fiction that expresses a pessimistic world view. The term comes from the publishing imprint série noire that in 1945 began to publish hardboiled detective fiction, the bulk of which was written by American authors such as Dashiell Hammett and Raymond Chandler. After the Second World War, French critics applied the term film noir to gloomy Hollywood films, many of which were adaptations of hardboiled literature. As these films were stylistically innovative in their use of elements such as chiaroscuro lighting, canted compositions and flashbacks, the word noir became a key concept in debates on film and television style.

The concept of Nordic noir was popularized by British literary critics to talk about translated Scandinavian crime literature after Stieg Larsson's Millennium (2005-2007) trilogy had become a worldwide phenomenon. Actually, this brand of popular literature was mainly Swedish (Bergman $2014,11)$. At the turn of the 2010 s, the concept was repeatedly used in discussions concerning popular Scandinavian crime films and television series (Hansen and Waade 2017, 5) akin to Forbrydelsen (The Killing, 2007-2012) and Bron/Broen (The Bridge, 2011-2018). These were not just any works in the crime genre, but ones that had an international appeal. Thus, Nordic noir should not be defined as a synonym for Nordic crime fiction. The global popularity of The Killing and The Bridge encouraged Nordic filmmakers and television producers to adapt and appropriate their conventions in the hope of reaching large audiences. Today, the concept of Nordic noir is more commonly associated with Nordic crime films and television series than with literature.

I build on Julie Grossman's (2015) view of adaptations as looking forward, so that the identity of the phenomenon does not lie in the original but in the adaptation. To fully comprehend how film and television producers have engaged with literary tradition, moreover, it is productive to understand Nordic noir as a style. Style can be understood as the systematic and significant use of the techniques of the medium (Bordwell 1997, 4). In the context of film and television, employing a specific style is a way of producing crime films and television series in an identifiable manner as 
Nordic noir, around which preproduction, narrative and marketing can all be organized. This is what Finnish television producers have been doing for the past few years.

The first season of Sorjonen (Bordertown), which was broadcast in 2016, was widely acclaimed as the first Finnish Nordic noir. Before its premiere, Finnish audiences were informed that the production company Fisher King hoped that Bordertown would 'gain popularity abroad a bit in the spirit of The Bridge and other Nordic noir series' (Lehtonen 2016, B3). Over one million viewers (in a country of five million) watched the opening episode and even though initial feedback was largely positive, 'many spectators complained that the series [...] resembles too closely the immensely popular The Bridge' (Koivuranta 2016, B4). Some critics even claimed that the first Finnish Nordic noir was nothing but 'a cheap copy of The Bridge' (Vanha-Majamaa 2017). There are similarities between Bordertown and its predecessor, there is no doubt about that. If it were otherwise, it would make little sense to assign the show to the category of Nordic noir. Despite such criticism, Bordertown won three Golden Venla Awards (Finnish awards for excellence in television), including the best drama series. By now the show has been shown in over 180 countries and it is available on Netflix (Oikkonen 2019). For Finnish television this is an unprecedented commercial and cultural accomplishment. As other producers are now trying to replicate the success, Finland is experiencing a Nordic noir boom: Karppi (Deadwind), Bullets, Ivalo (Arctic Circle) and Ratamo all premiered in 2018, not to mention the second season of Bordertown.

Nordic noir, if the phenomenon is to be properly understood, needs to be recognized as a style that can be adapted and appropriated. It is important to grasp that the style is not something to be simply 'reproduced, but rather something to interpreted and recreated', to borrow the words of Linda Hutcheon $(2013,84)$. In the rest of this chapter, I indicate how the style of Nordic noir is best defined and how Bordertown connects to it.

\section{Towards a Nordic noir style}

It is important to get a good understanding of the style of Nordic noir, as it enables us to understand how these films and television series guide the attention and responses of spectators, attracting not only domestic audiences, but capturing the attention of viewers all over the world. To state the obvious, not all films and television series discussed as Nordic noir are stylistically homogeneous. As Kim Toft Hansen and Anne Marit Waade have put it, 'a number of salient features can be found 
in many (but not necessarily all) dramas dubbed Nordic Noir' (Hansen and Waade 2017, 17). The style of Nordic noir needs to be defined in terms of family resemblances, to use Ludwig Wittgenstein's concept in which '[m]embers of a family resemble one another in various ways, but there need be no single collection of properties shared by everyone in the family' (Lakoff 1987, 16). Luis Miguel García Mainar makes a similar argument about thematic resemblances in Nordic noir in chapter 8 of the present volume. The Killing and The Bridge capture much of what people instinctively think of as Nordic noir. Therefore, they are commonly used as reference points in Nordic noir discussions. The Killing and The Bridge can be defined as prototypical Nordic noirs; that is, as the best example of what Nordic noir is. In the prototype theory, 'degree of category membership is determined by degree of similarity to a prototypical member' (Lakoff 1987, 142). The two shows need to be placed at the center of the definition of Nordic noir and stylistically different Nordic crime films and television series at its outskirts.

Film and television scholars have made numerous observations and initial arguments about the style of Nordic noir. Björn Nðrdfjörð argues that ' $[\mathrm{t}]$ he local specificity of earlier films has increasingly made way for the generic style of the international crime film, which has also completely swallowed up the art cinema credentials of the pioneering film Insomnia [NR, 1997]' (Nðrdfjörð 2015, 65). These international elements include conventions such as noir lighting, cliffhangers and rapid editing of chase sequences. Other critics contradict the first part of Nðrdfjörð's argument, claiming that 'the exoticism of the settings, landscape, light, climate, language and everyday life' continue to be important elements in Nordic noir (Jensen and Waade 2013, 260). A key question for Nordic noir scholars to explore is how the so-called local elements in Nordic noir correlate with the international conventions of the popular crime genre. The art-cinema atmosphere and sensibility of Nordic noir have received less attention, but in his seminal article on the topic Glen Creeber argues that 'these dramas are typified by [a] dimly-lit aesthetic [...] that is matched by slow and melancholic pace' (Creeber 2015, 22). In the context of popular film and television, these art cinema elements stem from modernist minimalism, which is best understood as a systematic reduction of expressive elements in a given form (Kovács 2007, 140).

Nordic noir needs to be analyzed as a type of popular modernism, to borrow Kimmo Laine's concept for the use of art cinema elements in popular works (2016, 171-184). The style of Nordic noir needs to be explored in the context of other crime films and television series in order to assess which of its stylistic features are unique. It is also important to differentiate between conventions used in the popular crime genre but not in Nordic noir. As a key example, close analysis makes 
evident how Bordertown adapts and appropriates stylistic elements from The Bridge and The Killing in its use of 1) modernist art cinema elements, 2) conventions of the popular crime genre and 3) Nordic regional elements. These are the three categories that I see as essential for Nordic noir.

\section{Slowness and modernist minimalism in Nordic noir}

Nordic noir adapts and paraphrases elements from modernist art works; even some of Bordertown's episodes have been named after modernist classics, a good example being Kevätuhri (The Rite of Spring). Here I focus on elements that connect Nordic noir to minimalist art films. This serves as a starting point for an explanation of why Nordic noir is often experienced as slow as, for example, in Creeber's description above of its 'slow and melancholic pace' or Hansen and Waade's understanding of 'the slow-paced narrative serial rhythm' $(2017,297)$ as one of its defining features. Similarly, in their take on Nordic noir Tobias Hochscherf and Heidi Philipsen emphasize the importance of 'the rather slow-paced, dialogue-based scenes' $(2017,17)$. Even though Nordic noir has been time and again called slow, relatively little is known about the nature of its slowness. To begin with, we need to ask how slow is slow and in what context.

To get a better understanding of the slowness of Nordic noir, it is worth focusing on average shot lengths (ASL). The ASL is the length of a television episode (without pre-credit sequences, recaps and credits), divided by the number of shots in it. As the ASL refers to cinematography (how long shots last) and editing (how often shots change), both of which are major areas of television style, it tends to correlate with the tempo in which the story is told. The figure is also useful in that it is comparable, which makes it suited for stylistic corpus analysis. Broad and reliable comparisons cannot be made yet, as metrical data on Nordic noir has not been extensively gathered and to do so would be a too big task for the purposes of this chapter. To circumvent the issue, I focus on the opening episodes The Killing and The Bridge, and compare those to that of Bordertown. Even though much can change as series develop, opening episodes are promissory notes for what is to come and thus give a good idea of what series are like as a whole (Mittell 2015, 67).

The ASL of the opening episode of The Killing is 4.4 seconds and that of The Bridge is 4.8 seconds, which indicates that in terms of cinematography and editing the shows share similarities. The ASL of Bordertown is exactly 5 seconds, which means it is stylistically close to the aforementioned 
series. More statistical research needs to be done on the issue, but these preliminary results support my argument that there really is a style of Nordic noir that Bordertown adapted, as the difference between the lowest and highest figures in the small corpus is only 0.6 seconds. In order to understand whether this constitutes slow editing in the contemporary media environment, some context is illustrative. Slow cinema, an art cinema trend that has much in common with minimalism, has received significant critical attention (De Luca and Jorge 2015; Çağlayan 2018). In comparison to these works, Nordic noir is anything but slow. To give an example, the ASLs of the Hungarian slow cinema auteur Béla Tarr vary from 32 to 240 seconds (Kovács 2013, 91). In contrast, the Nordic noir ASLs presented above are close to those of popular Hollywood films. The mean ASL of Hollywood films made around 2010 is somewhere between 4 and 5 seconds (Cutting and Candan 2015, 43). However, ASLs of contemporary Hollywood action films, many of which contain crime elements such as the Mission Impossible (1996-2018) series, can be as low as 2 seconds (Salt 2009: 377-378). Such fast editing is also found on television. The opening episode of CSI: Crime Scene Investigation's (US, 2000-2015) season 11, which premiered in 2010 when Nordic noir was gaining momentum, is only 2.8 seconds. As CSI: Crime Scene Investigation is the most popular television crime series ever (Turnbull 2014, 87), it is especially useful as comparative material, as it has in all probability shaped audiences' expectations on what television crime shows are like. For fans of the show and other similarly fast paced popular fictions, Nordic noir must have felt slow.

But in order to properly understand slowness, it is not enough to look at shot lengths alone. A long take of a high-speed car chase can feel fast whereas a much shorter take of a murder victim can feel slow, for example. To further complicate the matter, stylistic devices such as acting and music can make fast edited sequences feel even faster and slow edited sequences even slower. The visual style of CSI: Crime Scene Investigation is 'often described as glossy, excessive and fantastic' (Bull 2015, 68), which undoubtedly adds to the experience of fastness. Nordic noir, on the other hand, is typically described in opposite terms. For instance, Hochscherf and Philipsen see 'open forlorn spaces, muted lighting, [...] limited dialogue, monochromatic color design and studied moments of reflection' $(2017,16-17)$ as major characteristics in Nordic noir series. These minimalist elements are far removed from CSI: Crime Scene Investigation's maximalism.

When it comes to acting, popular television shows tend follow the principle of expressivity, which means 'a relation of directness between intentional states and their physical expression' (Smith 2004, 167). Moments of embodied transparency 'when we know exactly what the characters think' 
are enjoyable, as they 'make us feel like brilliant social players' (Zunshine 2012, 23 and 81). A fine example of embodied transparency is found in the opening episode of CSI: Crime Scene Investigation's season 11. In it the bomb specialist Kacey Monahan (Sienna Guillory) is exploring the remains of a bomb. In a medium close-up Monahan lifts her gaze from the remains to look at her colleague in the off-screen space: 'I may have found the bombers signature.' She utters the words with a playful voice and smiles happily, which indicates that to her forensic science is a game that she masters and thus enjoys playing: it is as if she has just solved a well-designed puzzle (figure 12.1). There is more to her words and expressions than that, as the viewer can easily get a sense that she is flirting with her colleague by playfully letting him know how good she is in her work. As the example indicates, acting in CSI: Crime Scene Investigation is overtly lively and expressive, even if some sequences rely on more static conventions.

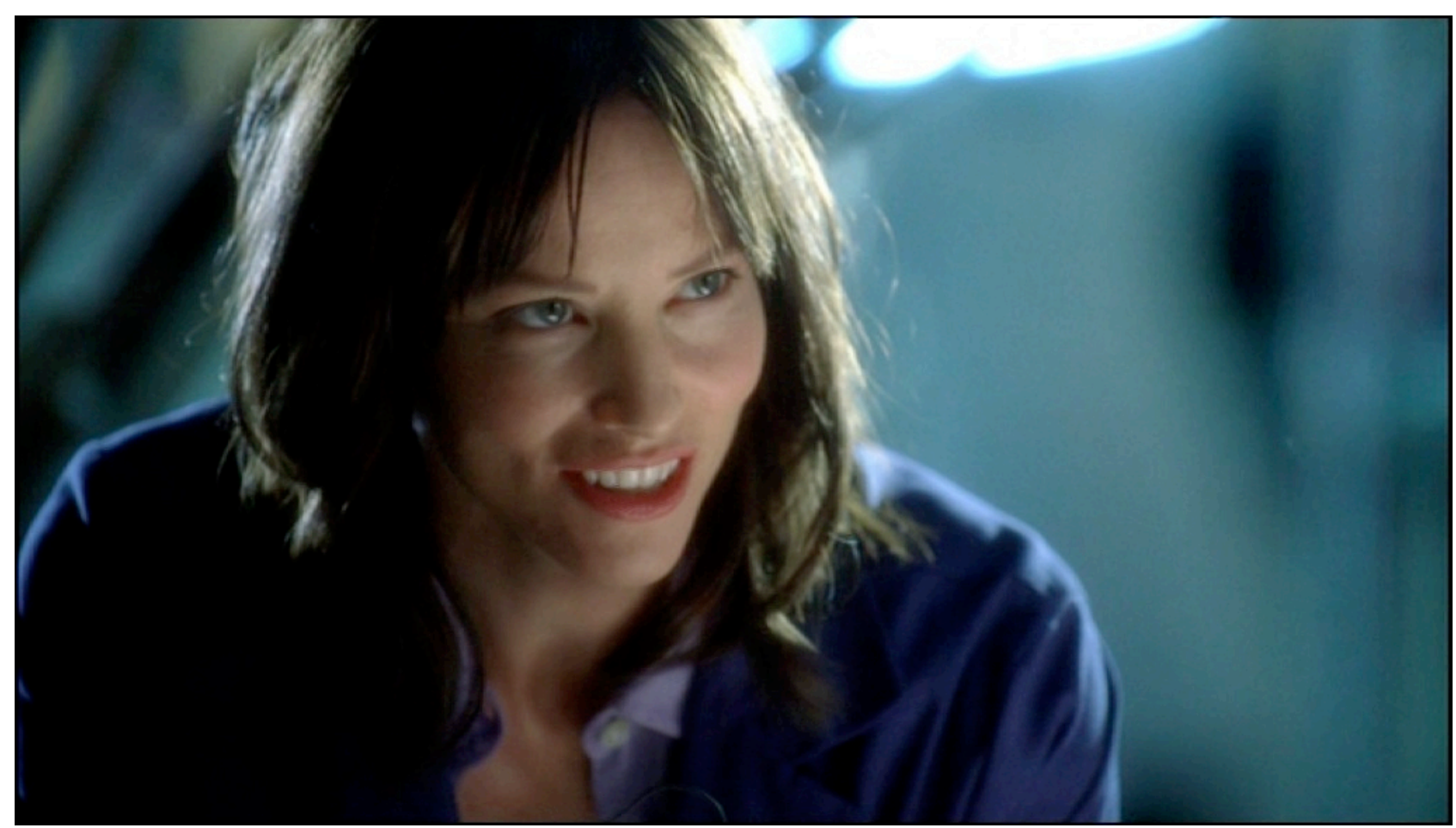

Figure 12.1

In contrast, Nordic noir acting is often minimalist, which makes the series feel significantly slower than their ASLs would suggest. In the end of the opening episode of The Killing, the police detective Sarah Lund (Sofie Gråbøl) makes a major discovery that can be compared to that of Monahan. Together with other police officers, Lund has been looking for signs of a crime on a vast field where personal items of a teenager gone missing were found. While talking on a phone with her husband in a medium shot, she notices something in the off-screen space. Two over-the- 
shoulder shots show a group of kids with fishing gear walking their bikes. Lund's face is somewhat expressionless, which makes it difficult for the audience to know what she is thinking (figure 12.2). The episode cuts to an extreme close-up of Lund's static eye towards which the camera tracks, emphasizing the enigma. In a medium shot she slowly lowers her phone, as she has lost her interest in the conversation. 'What's over there?' she asks her colleagues with her finger pointing towards the off-screen space where the kids went. As Lund learns about a waterway, she informs her Swedish romantic partner that she is going to miss the flight she had promised to take. The missing teenager is later found dead in the waterway. Similar acting is also found in The Bridge, as Saga Norén (Sofia Helin), the principal character of the series, is a relatively expressionless character. According to Hochscherf and Philipsen, 'the impossibility of reading her by her facial expressions suggests that she has some mild form of autism' $(2017,126)$. Indeed, Nordic noir often uses the conventions of neuro noir, a sub-genre of crime fiction 'featuring detectives whose neurological condition affects their thinking, influences their relationships, and both hinders and facilitates investigations' (Sweeney 2017, 231).

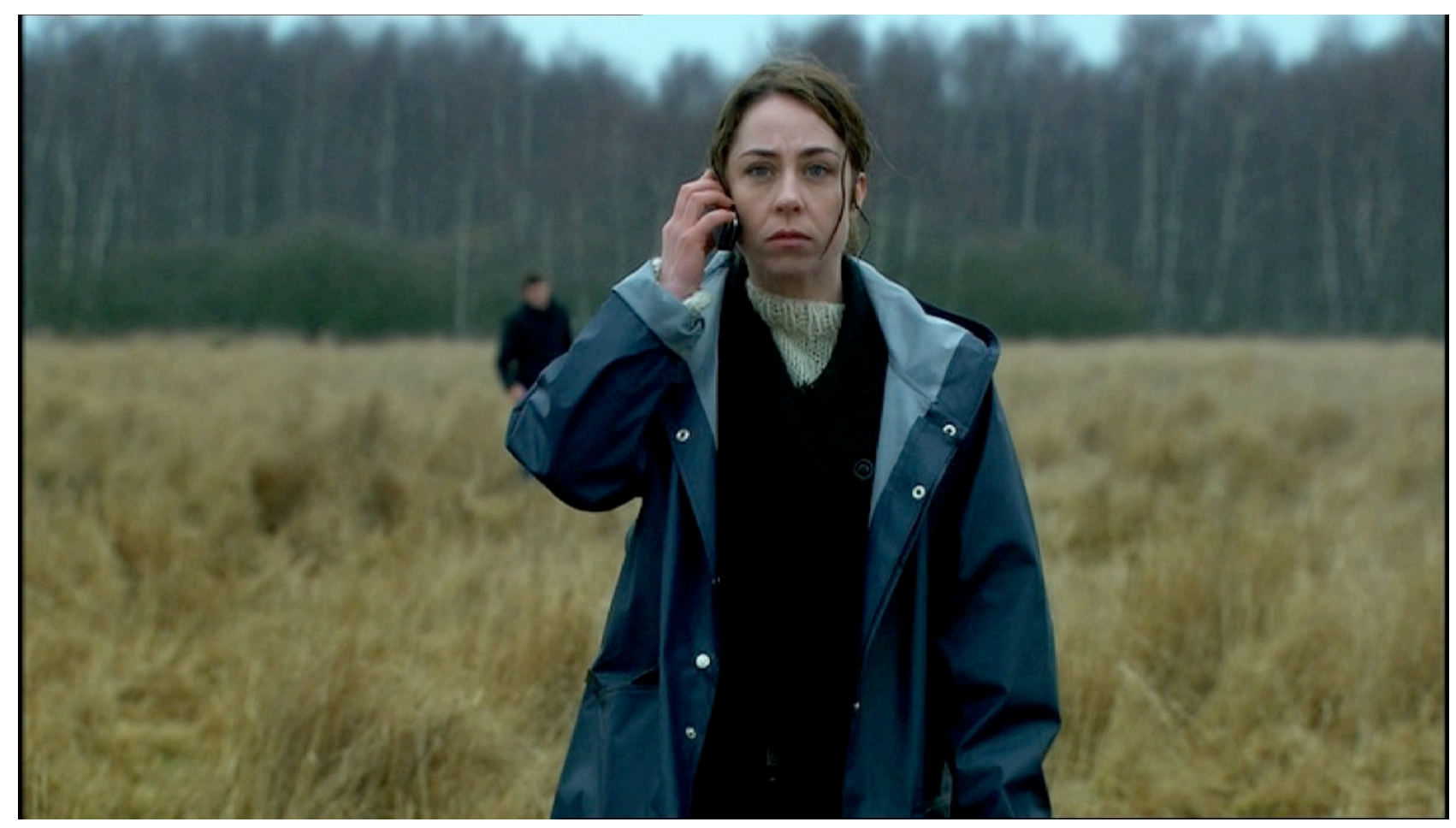

Figure 12.2

The makers of Bordertown connected their crime series to the tradition of Nordic noir by appropriating the minimalist acting style of The Killing and The Bridge. The opening episode of the series contains a sequence in which the police officer Kari Sorjonen (Ville Virtanen), the 
protagonist of the series, makes an important discovery. According to the showrunner Miikko Oikkonen, the character is a fusion of Sherlock Holmes and the brilliant yet neurotic Adrian Monk (Oikkonen 2019). It is a late evening in the sequence as police officers and forensic scientists are exploring the site where the body of a young woman has just been found. In a medium shot, Sorjonen, who has scarcely arrived at the scene, stands on a small cliff looking down with his flashlight turned on (figure 12.3). He slowly turns his head to the right and then towards the lake in the off-screen space. 'You were the first one here?' he calmly asks of one of the police officers. Getting a positive response, Sorjonen turns the flashlight off and turns around to walk away. 'We're in the middle of an investigation here,' his superior protests. 'This is no crime scene,' Sorjonen responds, astonishing everyone. Virtanen's minimalist acting has done nothing to express his character's thoughts. Sorjonen explains to others that the teenager was dead before she was pushed into the water from a boat. He remains calm and static as he stands on the rock, but he uses his hand to convincingly point at details on which he has built the interpretation. It turns out that he is correct.

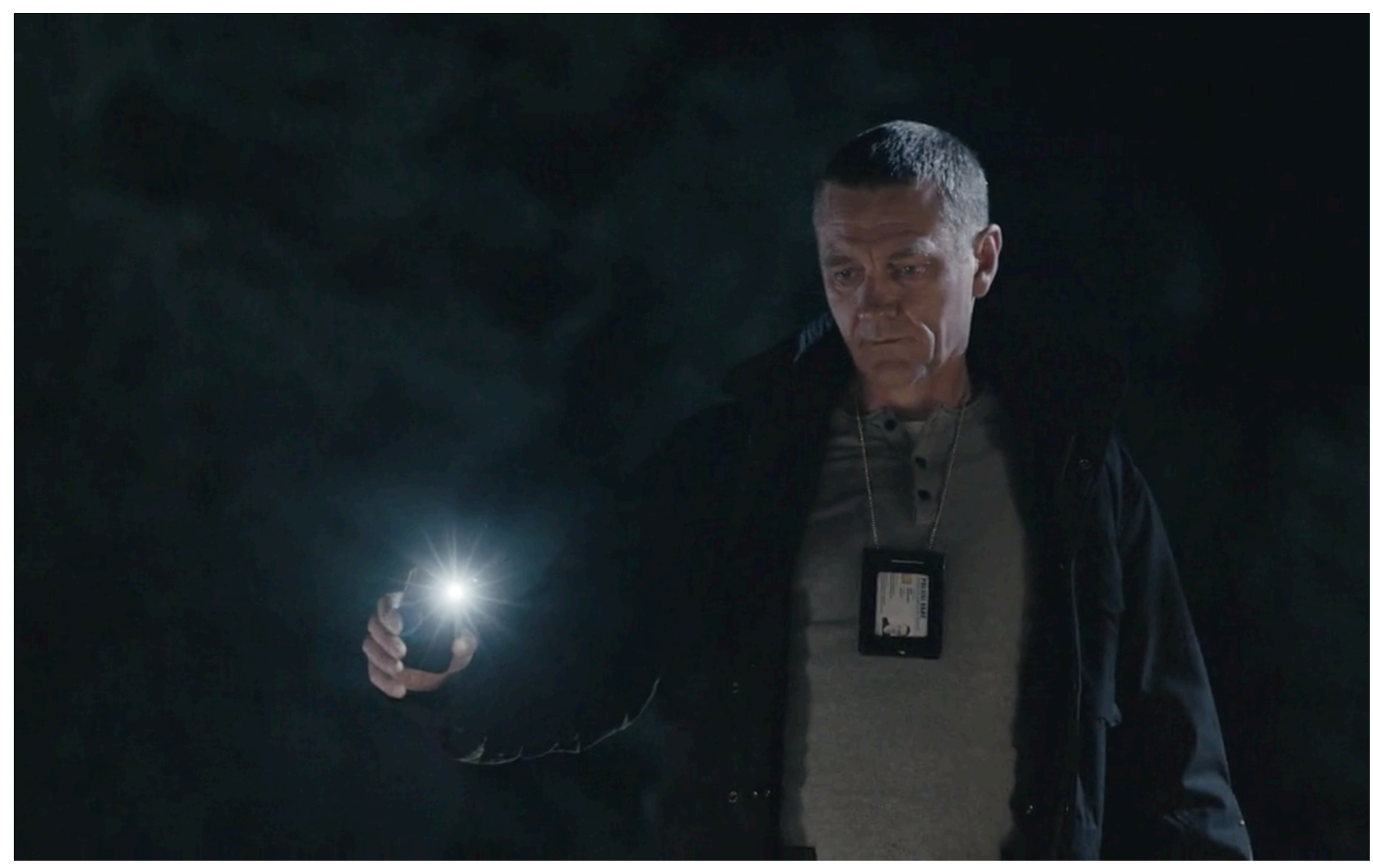

Figure 12.3

In these and many other examples, Bordertown paraphrases the minimalist acting conventions of The Killing and The Bridge. Such minimalism connects these television shows with Nordic 
modernist art cinema in which minimalism is a major tenet, as exemplified by the esteemed works of Carl Theodor Dreyer, Ingmar Bergman, Aki Kaurismäki, Roy Andersson and Ruben Östlund. Minimalist tendencies are evident in other Nordic arts as well, for example in the architecture of Arne Jacobsen and design of Alvar Aalto or the paintings of Vilhelm Hammershøj whose expressionless characters and still, quiet spaces are reminiscent of those seen in Nordic noir.

\section{Popular crime genre conventions in Nordic noir}

Nordic noir has a close connection to Nordic crime literature (Hansen and Waade 2017, 4-5), a connection not dissimilar from that of film noir and American hardboiled detective fiction (Neale 2000, 164-165). Even if some Nordic noirs do not belong to the popular crime genre, most do. Various conventions of the crime genre are evident in the style and narration of these works. For example, in its mise-en-scène Nordic noir circulates conventional crime fiction iconography such as police vehicles, murder weapons and dead bodies. It also uses narrative structures frequently employed in police investigations and thrillers of different kinds. Good examples are detectives, whether private or amateur, finding clues and slowly getting closer to identifying the culprit through a major enigma to be solved. As Nordic noirs commonly relies on such stylistic and narrative elements, the crime genre functions as a productive framework in their analysis.

Heta Pyrhönen argues that windows 'have a special significance in the detective story' $(2017,74)$. As she points out, different types of windows have important functions already in the early crime stories of Edgar Allan Poe and Arthur Conan Doyle. From the golden age detective fiction, windows and window-like surfaces found their way into contemporary crime films and television series such as CSI: Crime Scene Investigation, in which screens of computers and other gadgets are common. Similarly, in the first season of The Bridge, Pyrhönen analyses, 'the viewer is struck by the plethora of windows and window-like surfaces such as computers and television screens, and glass partitions. Characters stand by or are shown through windows or, they are in glass cubicles that serve as interrogation rooms' (Pyrhönen 2017, 75). When it comes to Nordic noir as a group style, characters stationed behind windows or observing through widows are common leitmotif. In my analysis I focus on scenes in which characters are sitting in cars.

In the opening episode of the first season of The Bridge, the police investigators Saga Norén and Martin Rohde (Kim Bodnia) have received a CD from the supposed murderer of two women. The 
camera shows Norén and Rohde in a medium shot through the side glass of Norén's car. A light reflecting on the window through which the characters are seen accentuates the camera's outside position and its distanced way of looking at the characters. Without uttering a word, Rohde plays the $\mathrm{CD}$, which turns out to contain a message delivered in a distorted voice: 'Sorry about the drama, it's hard to make oneself heard today. I assume I have your attention now.' As the voice recording plays, the camera slowly tracks towards the inexpressive faces of Norén and Rohde, intensifying the drama, until they are seen in a medium close-up. They are looking at each other. 'The women were just the beginning. We got interesting times ahead of us,' the message ends. It is difficult not to notice the mullion, which divides the window in two and compositionally separates the characters, as if emphasizing their different nationalities and distinct personalities, which now need to be overcome as they have to work together. People are walking past the car behind the windows Martin is sitting in front of, which further emphasizes the physical stasis and quietness of the characters. According to Tommi Römpötti, filmmakers like to set scenes in cars, as they are small and containing spaces that force characters to communicate and enter each other's territory (Römpötti 2012, 77). Norén and Rohde need to communicate, if they are to solve the case, but the result is the total opposite: after looking at each other, Rohde turns his gaze towards the windshield, after which he looks back at Norén, but now she turns her gaze away. Here are two police investigators who are as distant from one another as the audience behind the window is from them.

The opening episode of the first season of The Killing contains a sequence in which the police detective Sarah Lund is driving her son to his grandmother. The camera is with the characters in the moving car. The sequence is divided into several shots, all of which are claustrophobic close-ups or extreme close-ups. November rain is whipping the car behind the windshield and the side glasses, which can be seen in several of the shots. Many of the shots are in soft focus, which can make it look as if the camera is at times observing the characters from behind the wet windows. 'So, we're not moving after all?' the son asks wondering whether Lund and her boyfriend have changed their plans about moving to Sweden. 'I have something to do first,' she replies in passing, but does not inform him that she is working on the case of a missing teenager, which keeps her mind occupied. Lund is not interested in their planned move or in her son, a theme that is emphasized by her failing to remember the name of his ice hockey team. As the windows of the car are covered with water, the landscape cannot be properly seen, which together with the close camera distance makes the sequence enclosed. The car separates the characters from the rest of the world, giving them a chance to have an intimate discussion, but Lund's thoughts are elsewhere, as she like many other Nordic noir protagonists (Hochscherf and Philipsen 2017, 190) including Saga Norén and Kari 
Sorjonen, is a workaholic. In cars characters are close to one another, but they do not have to look at each other in the eyes, which is another reason why they are common in Nordic noir that often depicts estrangement and communication problems even among family members. In Nordic noir families are rarely happy and homes ideal, if even tolerable; this is a major move away from the ideals of the people's home (folkhemmet).

In Bordertown the camera frequently provides a distanced way of looking at characters, as in The Killing and The Bridge, which is a further indication of an adapted style. In the opening episode of the series, Lena Jaakkola (Anu Sinisalo) who works for the Federal Security Service of the Russian Federation, is exploring the case of her missing daughter on her own time. In a conventional Nordic noir sequence, the camera shows her through the windshield of her parked car. Sitting on the driver's seat, she directs her gaze at the wing mirror. The camera pans right, emphasizing her small bodily movement. What follows is an extreme close-up of the wing mirror in which a reflection of a car driving from a yard to the street can be seen. The widows and the mirrors emphasize her distanced way of seeing the world around her. From here the episode cuts to an extreme long shot in which the car is about to drive past her. She is again seen through the windshield of her car, but this time from an angle that shows the car driving past her. The camera guides the audience to focus on her eyes while she puts her gun away and starts the car. What follows is a long moving take in which the camera is stationed behind Jaakkola's right shoulder on the backseat. The careful placement of the camera enables the audience not only to see her driving, but also the car she is following as well as her watchful eyes on the rear-view mirror. The road behind her, however, cannot be seen. The windows and the mirror emphasize the audience's distanced position, as little information is given about her thoughts, emotions and background. Together with the monotonous colors scheme and low industrial music, the cinematography guides the audience to think that Jaakkola is not only lonely and melancholic, as she has lost her daughter, but also angry and possibly about to carry out revenge.

The task of analyzing popular crime genre elements that Nordic noir does not use cannot be carried out in the space of this chapter. However, I want to point out that the "coolness" of the crime films of Quentin Tarantino is missing from Nordic noir, even though it has been appropriated in numerous crime films and television series. Nordic noir rarely delivers flashy dialogue or celebrates violence, as many fast-paced crime films and television series do. In Nordic noir the focus is on the horror of crime and its impact on victims and surrounding society. Violence is designed to horrify, not to be admired or to entertain. Comic elements, which are common in the cinema of Tarantino, 
are also missing. Nordic noir is rarely overtly funny, but it tends to contain some deadpan humor, as in the interactions between Norén and Rohde in The Bridge. The lack of coolness and comedy adds to the dark and pessimistic tone of Nordic noir.

\section{Nordic regional elements in Nordic noir}

In the style of Nordic noir, elements of modernist art cinema and popular crime genre, which were analyzed above, are fused with Nordic regional elements. This is a wide category that contains everything from hand knitted sweaters and local nourishment via architecture and design to nature and landscapes. For people of the Nordic region, modernist and popular devices function as elements of defamiliarization: what is customary and secure often appears threatening on screen. For international audiences, it is largely the other way around: the modernist and popular techniques are familiar from numerous films and television series, but in their context Nordic regional elements function as exotic Nordicana. This is evident in various comments online in which international viewers express their admiration of Nordic forests and lakes, for example.

Bordertown, just like The Killing and The Bridge that preceded it, represents the Nordic region as a playground of international trans-border crime, sexual abuse and political corruption. This is not how the five Nordic countries are typically represented and imagined abroad. Outside the region, to borrow Michael Booth, the countries are often naively believed to be 'the promised lands of equality, easy living, quality of life and home baking' (Booth 2015, 7). While there are foreigners who have settled here still and hold these views, for sure, negative aspects and dark undercurrents of the welfare states have received less attention abroad. On a global scale, Nordic noir provides challenging perspectives on the welfare states, all of which are traditionally highly ranked in welfare surveys, and guides audiences to reimagine them. Biting welfare state criticism has been present in the modernist works of Kaurismäki, Anderson and Östlund for years, but internationally their films have reached only niche audiences, unlike Nordic noir.

The Killing introduced the darkness of never-ending November as a key stylistic feature of Nordic noir (Hochscherf and Philipsen 2017, 101, 115; Hansen and Waade 2017, 170-171). This makes the welfare states appear not only cold but also frightening. In the first episode in the first season of The Killing, the search for the missing teenager has mostly taken place in daylight. In the end of the episode, a car is lifted from a water way in evening twilight. As daylight fades away, colors start to 
disappear and the milieu becomes monochromatic. Soon, it is pitch black and police officers use flashlights, as they inspect the found car. It is difficult to properly see what happens on the screen. There is a realistic motivation for this, as winter days are short in the Nordic region. The sequence uses parallel editing, cutting between the police officers searching the car from which they find the tied body of the murdered teenager, and her father who is driving his van to the search site, as he is having a conversation with his wife who is in their home. Electric lights are on in the home, but they can only barely illuminate the space. Even if one would suppose that the wife has merely dimmed the lights, the interpretation would not stand close scrutiny, as various other interiors in the series are lit the same way, many of them public spaces. It is as if the society were wrapped in darkness.

Instead of adapting the element of darkness as such, Bordertown paraphrases it in significant ways. In the opening of the first episode in season one, Sorjonen and other police officers are exploring a home where the body of a young girl has been found. Some of the lights are on, but the interior is dimly lit. The lighting scheme is reminiscent of The Bridge, which substituted the November darkness and high contrasts of lit and dark areas of The Killing with a more even lighting scheme that resembles the blue hour. The police officers carry flashlights as they inspect the house, but do not turn on the lights or open windows. There is no realistic motivation for the lighting scheme, but it adds to the frightening atmosphere of the sequence and stylistically connects the series to the two others shows. From this dark Helsinki location, the show moves to sunny Lappeenranta where Sorjonen and his family move, believing it to be a place of peace and quiet. Unlike many Nordic noirs that are set in winter months, Bordertown is set in summer, and the move makes the most out of the bright and hard Nordic sunlight, as if to emphasize the family's impression of the small town. Although the sun shines and the landscape is green and blue from the region's forests and lakes, interiors are often dim and colors muted, even the police station where Sorjonen works. There is no realistic motivation for this either. The real interrogation room at Lappeenranta police station is well lit unlike the one seen in the series, the detective sergeant Ilkka Vainikka points out (Kivimäki 2018). In summer time, Nordic interiors are regularly exposed to glare of daylight, whether the inhabitants like it or not. This is a theme well-handled in Erik Skjoldbjærg's film Insomnia, which Nðrdfjörð sees as a pioneering Nordic noir. To Sorjonen's disappointment, Lappeenranta’s idyllic façade turns out to hide pockets of hell. These are dark places in which crime dwells, such as remote cabins and private garages. In Nordic noir, exterior lighting is often realistically motivated with seasons of the year, typically with November darkness, but dim interior lighting and muted color palette are not. These stylistic decisions create a sense of light fading away into the night, 
slowly leaving the Nordic welfare states in darkness where crime reaps its harvest. Contextually, the style of Nordic noir is connected to problems of social democracy in the age of increasing globalization, complex international crises and decay of middle-class identities.

\section{Conclusions}

In this chapter I have argued that the style of Nordic noir can be understood as a fusion of 1) characteristics of modernist art cinemas, 2) conventions of the popular crime genre and 3) elements typical to the Nordic region. These are used to create a tone that is dark and melancholic, expressing contemporary fears and uncertainties. While the elements obviously are not original as such, the combinations are idiosyncratic. This is what is unique in the style. As stated in the opening of this chapter, not all Nordic noirs are alike: there is a scale of representational possibilities from weak to strong intensity. The more Nordic noir features a crime film or television series uses, the more representative it is. And vice versa; a work can use only some Nordic noir features and still be recognizable as Nordic noir.

The makers of Bordertown adapted and appropriated stylistic traits familiar from the The Killing and The Bridge, which had adapted elements from older works. As a result, it became possible for them to advertise Bordertown as the first Finnish Nordic noir and to sell it to a global audience making Finnish television history. In the words of Oikkonen, 'abroad the first season has received almost solely positive feedback' (2019). It is worth emphasizing that the show differs from The Killing and The Bridge in various ways, for example in its use of bright sunlight. This is 'repetition without replication' (Hutcheon 2013, 7), not copying as some viewers suggested.

The definition I have proposed is productive in the analysis of Nordic noir. First of all, it indicates what Nordic noir is. The definition is not incompatible with the often-repeated argument that Nordic noir is a brand, as I argue that it is a style that gives substance to the brand. Similarly, one can think about Nordic noir as a genre that is largely defined by style. Second, the definition explains the international cross-audience appeal of Nordic noir, its popularity among crime fiction fans and highbrow audiences, its popularity among spectators living in the Nordic region and spectators living outside the region. Third, the definition emphasizes Nordic noir's embeddedness not only in film and television history but in other arts as well, which is a matter that needs further analysis. Fourth, the definition explains how Nordic noir can be appropriated even outside the 
Nordic region. Good examples of television series that do this are Shetland (2013-) and Fortitude (2015-). Indeed, Nordic noir is a group style that can be copied, paraphrased and alluded to, as numerous filmmakers and television producers around the world have shown.

\section{Sources}

Bergman, Kerstin. 2014. Swedish Crime Fiction: The Making of Nordic Noir. Milan: Mimesis International.

Booth, Michael. 2015. The Almost Nearly Perfect People: Behind the Myth of the Scandinavian Utopia. London: Vintage.

Bordwell, David. 1997. On the History of Film Style. Cambridge et al.: Harvard University Press.

Bull, Sofia. 2015. "Televisual Forensics on the Edge of Chaos: Postgenomic Complexity in CSI: Crime Scene Investigation.” Screen 56 (1): 64-80.

Çağlayan, Emre. 2018. Poetics of Slow Cinema: Nostalgia, Absurdism, Boredom. Basingstoke: Palgrave Macmillan.

Creeber, Glen. 2013. "Killing Us Softly: Investigating the Aesthetics, Philosophy and Influence of Nordic noir Television." Journal of Popular Television 3 (2): 21-35.

Cutting, James E. and Candan, Ayse. 2015. "Shot Durations, Shot Classes, and the Increased Pace of Popular Movies.” Projections: The Journal of Movies and Mind 9 (2): 40-58.

Grossman, Julie. 2015. Literature, Film, and Their Hideous Progeny: Adaptation and ElasTEXTity. Basingstoke: Palgrave Macmillan.

Hansen, Kim Toft and Anne Marit Waade. 2017. Locating Nordic noir: From Beck to The Bridge. Basingstoke: Palgrave Macmillan. 
Hochscherf, Tobias and Philipsen, Heidi. 2017. Beyond the Bridge: Contemporary Danish Television Drama. London and New York: I. B. Tauris.

Hutcheon, Linda. 2013. A Theory of Adaptation. London and New York: Routledge.

Jensen, Pia Majbritt and Waade, Anne Marit. 2013. "Nordic noir Challenging the 'Language of Advantge': Setting, Light and Language as Production Values in Danish Television Series.” Journal of Popular Television 1 (2): 259-265.

Kimimäki, Petri. 2018. “Oikea rikospoliisi katsoi Sorjosen: 'Minua ei auta yhtään, että laitan sormen ohimolle'.” Yle, 25 November. Accessed 24 January 2019: https://yle.fi/uutiset/3-10520429

Koivuranta, Riikka. 2016. "Sorjonen vie kotimaista rikossarjagenreä uuteen aikaan." Helsingin Sanomat, 24 October, B4-B5.

Kovács, András Bálint. 2007. Screening Modernism: European Art Cinema, 1950-1980. Chicago and London: The University of Chicago Press.

Kovács, András Bálint. 2013. The Cinema of Béla Tarr: The Circle Closes. London and New York: Fallflower Press.

Laine, Kimmo. 2016. "Popular Modernism.” In Finnish Cinema: A Transnational Enterprise, edited by Henry Bacon, 171-184. Basingstoke: Palgrave Macmillan.

Lakoff, George. 1987. Women, Fire, and Dangerous Things: What Categories Reveal about the Mind. Chicago and London: The University of Chicago Press.

Lehtonen, Veli-Pekka. 2016. "Jussi-voittajien palkkiot maksamatta: elokuvayhtiö maksuvaikeuksissa." Helsingin Sanomat, 6 September, B3

De Luca, Tiago and Jorge, Nuno Barradas. 2015. Slow Cinema. Edinburgh: Edinburgh University Press. 
Mittell, Jason. 2015. Complex TV: The Poetics of Contemporary Television Storytelling. New York and London: New York University Press.

Neale, Steave. 2000. Genre and Hollywood. London and New York: Routledge.

Nðrdfjörð, Björn. 2015. “Crime Up North: The Case of Norway, Finland and Iceland.” In Nordic Genre Film: Small Nation Film Cultures in the Global Marketplace, edited by Tommy Gustafsson and Pietari Kääpä, 61-75. Edinburgh: Edinburgh University Press.

Oikkonen, Miikko. 2019. "Nordic noir Suomessa.” Presentation at Nordic Culture Point in Helsinki, 2 March.

Pyrhönen, Heta. 2017. "On the Role of Windows in Bron/Broen.” In Noin seitsemän taiteen poika: Kirjoituksia elokuvasta ja muista taiteista, edited by Kimmo Laine, Pasi Nyyssönen, Hannu Salmi and Jaakko Seppälä, 74-81. Turku: Faros.

Römpötti, Tommi. 2012. Vieraana omassa maassa: suomalaiset road-elokuvat vapauden ja vastustuksen kertomuksina 1950-luvun lopusta 2000-luvulle. Jyväskylä: Jyväskylän yliopisto.

Salt, Barry. 2009. Film History and Technology: History and Analysis. London: Starword.

Smith, Murray. 2004. Engaging Characters: Fiction, Emotion, and the Cinema. Oxford: Clarendon Press.

Sweeney, Susan Elizabeth. 2017. "Unusual Suspects: American Crimes, Metaphysical Detectives, Postmodernist Genres." In A History of American Crime Fiction, edited by Chris Raczkowski. Cambridge: Cambridge University Press.

Turnbull, Sue. 2014. The TV Crime Drama. Edinburgh: Edinburgh University Press.

Vanha-Majamaa, Anton. 2017. "Suomalaisessa televisiossa jäljitellään ulkomaisia sarjoja ja aliarvioidaan yleisöä.” Apu, 17 March. Accessed 10 January 2019:

https://www.apu.fi/artikkelit/suomalaisessa-televisiossa-jaljitellaan-ulkomaisia-sarjoja-jaaliarvioidaan-yleisoa 
Zunshine, Liza. 2012. Getting Inside Your Head: What Cognitive Science Can Tell Us about Popular Culture. Baltimore: The Johns Hopkins University Press. 